\title{
Research on the Situation of Corporate Culture Construction of State-owned Power Companies
}

\author{
Wang Han $^{1, *}$, Cheng Jiaxu ${ }^{1}$, Cheng Jiaxu ${ }^{1}$ \\ ${ }^{1}$ State Grid Energy Research Institute Co.,Ltd., Beijing, 102209, China \\ * Corresponding author's e-mail: wanghan@sgeri.sgcc.com.cn
}

\begin{abstract}
State-owned state-owned enterprises reform and power system reform are two major reforms currently facing stateCorporate culture is an important source of corporate core competitiveness and a key element of a world-class company with global competitiveness. As a large-scale responsible central enterprise, the state-owned power company is the foundation of the Communist Party's governance, an important force for maintaining political stability, and a "heavy instrument of the great power" that the party and the people trust and rely on. It must closely follow the requirements of the Party Central Committee and promote the building of a cultural power through culture. This article analyzes the situation that the state-owned power companies are facing in the development of corporate culture, and provides a useful reference for related enterprises in the development of corporate culture.
\end{abstract}

Keywords: Corporate Culture, State-owned Power Company, Cultural Construction.

\section{INTRODUCTION}

Culture is an important force for the survival and development of a nation. The unique, broad and profound Chinese culture provides a strong spiritual support for the Chinese nation to overcome difficulties and continue to thrive. We must adhere to the path of socialist cultural development with Chinese characteristics, stimulate the cultural innovation and creativity of the entire nation, and build a socialist cultural power.

In recent years, the ice-breaking round of deepening reforms has moved forward. With the in-depth advancement of state-owned assets and state-owned enterprise reforms and power system reforms, stateowned power companies are facing dual reform pressures. The contradictions and problems that need to be resolved have become more complex and reform tasks have become more onerous. State-owned power companies not only need to make rapid adjustments in the management system and mechanism, but also need to constantly strengthen their reform concepts in order to adapt to the current reform situation.

\section{THE CULTURAL POWER STRATEGY POINTS OUT A NEW DIRECTION FOR THE CONSTRUCTION OF CORPORATE CULTURE}

In October 2011, the Seventeenth Central Committee of the Communist Party of China deliberated and approved the "Decision of the Central Committee of the Communist Party of China on Several Major Issues Concerning Deepening the Reform of the Cultural System and Promoting the Great Development and Prosperity of Socialist Culture", which clearly stated that "adherence to the development of socialist culture with Chinese characteristics road, work hard to build a socialist cultural power" and put forward the goal of cultural reform and development in 2020, which provides a new concept and thinking for the implementation of the strategy of promoting cultural power.[1]

Since the 18th National Congress of the Communist Party of China, the Party Central Committee with Comrade Xi Jinping at its core has attached great importance to cultural construction, raised cultural construction to a new historical height, and established the system of adhering to the guiding position of Marxism in the ideological field as socialism with Chinese characteristics. A fundamental system of the institutional system. Adherence to the socialist core value 
system has also been incorporated into the basic strategy for upholding and developing socialism with Chinese characteristics in the new era. Cultural self-confidence, road self-confidence, theoretical self-confidence, and system self-confidence are listed as the "four selfconfidence" of socialism with Chinese characteristics.

The report of the 19th National Congress of the Communist Party of China clearly pointed out that "culture will rejuvenate the country and the nation will be strong. Without a high degree of cultural confidence and cultural prosperity, there will be no great rejuvenation of the Chinese nation. We must adhere to the path of socialist cultural development with Chinese characteristics, stimulate the cultural innovation and creativity of the entire nation, and build a socialist cultural power." This further clarifies the basic strategy for cultural construction in the new era.

In October 2019, the Fourth Plenary Session of the 19th Central Committee of the Communist Party of China deliberated and approved the Decision of the Central Committee of the Communist Party of China on Several Major Issues Concerning Upholding and Improving the Socialist System with Chinese Characteristics and Promoting the Modernization of the National Governance System and Governance Capacity. The document states that "it is necessary to uphold and improve the system for the prosperity and development of advanced socialist culture, and consolidate the common ideological foundation for the unity and struggle of all people." This further clarifies the major principles and directions for adhering to the development path of socialist culture with Chinese characteristics.

In September 2020, General Secretary Xi Jinping used the "Four Importance" to reaffirm the important status of cultural construction in his speech at the forum of representatives of experts in the field of education, culture, health and sports. He pointed out that "culture is an important content to promote the overall layout of the 'five in one' and coordinate the promotion of the four comprehensive strategic layouts; to promote high-quality development, culture is an important fulcrum; to meet the people's growing needs for a better life, culture is an important factor; to overcome various risks and challenges on the road ahead, culture is an important source of strength." This has once again clarified the important significance of the prosperity and development of socialist culture for socialist modernization.

In October 2020, the Fifth Plenary Session of the 19th Central Committee of the Communist Party of China reviewed and approved the "Proposals of the Central Committee of the Communist Party of China on Formulating the Fourteenth Five-Year Plan for National Economic and Social Development and the Long-term Goals for 2035" (below Referred to as the "Planning "Proposal"), clearly put forward the strategic goal of building a cultural power in 2035 . This is the first time since the Sixth Plenary Session of the Seventeenth Central Committee of the Party proposed to build a socialist cultural power, the Party Central Committee has clarified a specific timetable for building a cultural power. It provides an action guide for promoting the building of a cultural power in the new journey of comprehensively building a socialist modern country, and clarifies the direction for us to deeply understand the new mission of cultural construction in the new era and create new glory for Chinese culture. According to the planning "Recommendations", by 2035, my country will be built into a country with a strong culture, education, talent, sports, and healthy China. The quality of its citizens and the level of social civilization will reach new heights, and the country's cultural soft power will be significantly enhanced. The planning "Proposal" made strategic and overall planning and design, put forward the basic ideas for cultural construction in the next five years, and dedicated a part to the deployment of cultural construction. It points out that it is necessary to prosper and develop cultural undertakings and cultural industries, improve the country's cultural soft power, and start from three aspects: improving social civilization, improving public cultural services, and improving the modern cultural industry system, and deploy key tasks for future cultural construction.

State-owned power companies, as large-scale responsible central enterprises, are important participants, promoters and practitioners of the cultural power strategy. On the one hand, the cultural power strategy provides a fundamental follow and goal direction for the company to promote cultural development and strengthen corporate culture from two levels of top-level design and bottom-level logic. State-owned power companies must accurately grasp the important significance and rich connotation of the cultural power strategy, and use this guidance to continuously expand the connotation and extension of the company's corporate culture, and improve the construction of the corporate culture system. On the other hand, the construction of the corporate culture system and content design of state-owned power companies must not only reflect corporate characteristics, but also fully integrate with the connotation of the cultural power strategy, and use cultural business as a strong support and strong driving force to promote cultural power.[2]

\section{COMPREHENSIVE DEEPENING OF REFORMS BRINGS NEW CHALLENGES TO CORPORATE CULTURE CONSTRUCTION}

In recent years, the big wheel of deepening reform has broken the ice and moved forward. With the in-depth advancement of the reform of state-owned assets and state-owned enterprises and the reform of the power system, state-owned power companies are facing dual 
reform pressures. The contradictions and problems that need to be resolved have become more complicated and the reform tasks have become more onerous. Stateowned power companies not only need to make rapid adjustments in the management system and mechanism, but also need to constantly strengthen their reform concepts in order to adapt to the current reform situation.

\subsection{The Reform of State-owned Assets and State-owned Enterprises Accelerates Comprehensively}

Compared with the past, the new round of stateowned and state-owned enterprise reform involves a higher level, a broader scope and a deeper level, and is extremely exploratory, challenging and risky. This requires a more cohesive, contemporary, and supportive corporate culture as a strong backing for reform.

In June 2020, the 14th meeting of the Central Deep Reform Commission deliberated and approved the "Three-year Action Plan for State-owned Enterprise Reform (2020-2022)" (hereinafter referred to as the "Plan"). This provides a programmatic document for further deepening the reform of state-owned enterprises in the new development stage, and provides specific construction drawings for the implementation of the " $1+\mathrm{N}$ " policy system and top-level design of the stateowned enterprise reform in the future. The "Plan" pointed out that through the implementation of the three-year action of the reform of state-owned enterprises, significant results should be achieved in the formation of a more mature and more stereotyped modern enterprise system with Chinese characteristics and a state-owned asset supervision system based on capital management, and promote the optimization of the state-owned economy layout and structural adjustment Obvious results have been achieved in the above-mentioned efforts to strengthen and optimize state-owned capital and state-owned enterprises, and effectively enhance the competitiveness, innovation, control, influence and risk resistance of the state-owned economy. The "Plan" requires state-owned enterprises to become market players with core competitiveness. State-owned enterprises must play a greater role in leading innovation, play a leading role in improving the level of the industrial supply chain, play a special role in safeguarding the livelihood of the society and responding to major challenges, and play a fundamental role in maintaining national economic security and slowing down.

In January 2021, Liu He presided over the fifth meeting of the State-owned Enterprise Reform Leading Group of the State Council. The meeting emphasized that to implement the three-year action plan, we must grasp "one grasping hand, four cuts". It is necessary to effectively strengthen the unity of party leadership and improve corporate governance; improve efficiency and enhance corporate vitality; focus on innovation and strengthen innovation incentives; resolve risks and highlight main responsibilities and main businesses; standardize accounting and accelerate the establishment and improvement of state-owned economic statistical indicator systems and Evaluation system.

\subsection{The New Round of Power System Reform has Fully Entered a Period of Deep Water}

With the intensive promulgation of a number of policy documents to promote the construction of the power market, the external market environment faced by state-owned power companies has become more complex and changeable, and a corporate culture that can gather people's hearts, conform to public opinions, and appreciate public sentiment is needed as a "stabilizer" in the reform period.[3]

After the 2015 "Implementation Opinions on Promoting Power Market Construction" and supporting documents were issued, the new round of power system reform continues to make efforts in multiple aspects such as the reform of transmission and distribution prices, the construction of incremental distribution networks, the transformation of power market trading mechanisms, and the construction of power spot markets. This fundamentally urges grid companies to rapidly transform their original development and profit models.

In October 2018, relevant national ministries and commissions intensively issued the "Implementation Opinions on Promoting the Reform of Transmission and Distribution Price", "Implementation Opinions on Promoting the Construction of Electricity Market", "Implementation Opinions on the Establishment and Standardization of Electricity Trading Institutions", and "Regarding Orderly "Implementation Opinions on the Development of Electricity Use Plans", "Implementation Opinions on Promoting the Reform of the Electricity Sales Side", and "Guiding Opinions on Strengthening and Standardizing the Supervision and Management of Coal-Fired Captive Power Plants". 6 supporting documents for the power system reform, involving the reform of transmission and distribution prices, power In terms of market-oriented transactions, power-selling reforms, and market-oriented transactions of distributed power generation, we continue to accelerate the in-depth advancement of a new round of power reform.[4]

In December 2020, the National Energy Administration successively issued two documents: "Notice of the National Energy Administration on Further Improving the System of Power Dispatching Transactions and Market Order Joint Plant-Grid Meeting System" and "Measures for Settlement of Electricity Charges by Power Generation Companies and Grid Companies. The two documents have revised and improved the original documents from the perspective of adapting to the continuous advancement of the power 
system reform and the continuous deepening of the power market construction mechanism. The issuance of the document further coordinated and smoothed the multi-party markets such as power generation companies, grid companies, power dispatch agencies, power trading agencies, power distribution companies, and power users, and put forward higher regulatory requirements for the company's power supply and power sales.

State-owned power enterprises, as large-scale stateowned energy enterprises, are not only one of the important subjects in the reform of state-owned assets and state-owned enterprises and the reform of the power system, but also an important driving force for comprehensively deepening the reform.

On the one hand, the deepening of reform requires the company to change its original development mode, and promote the company's transformation and development by revitalizing existing assets, expanding incremental assets, innovating business management models, and changing operating systems and mechanisms. This requires corporate culture as a spiritual force to penetrate and penetrate all aspects of the company's reform and development, so as to qualitatively improve the company's internal spirit.

On the other hand, the mixed reform orientation required by the reform of state-owned assets and stateowned enterprises and the diversified development of the market brought about by the power reform have prompted the company to make active attempts to promote the mixed reform process in order to meet the needs of reform and development and respond to external market competition. The diversification of investment subjects will inevitably bring more diversified ideas and ways of thinking to the company. This requires the company to integrate and reorganize the company's original cultural heritage and externally introduced new ideas, and to build a unified corporate culture system to unite people and gather forces to form a powerful force that promotes the company's overall development.

\section{CONCLUSION}

The continuous deepening of the reform of stateowned assets and state-owned enterprises and the reform of the power system, the continuous turbulence in the international environment, and the profound changes in group management and control models have promoted the diversification of the main body of state-owned power enterprises, the public opinion environment in which the enterprises are located, and the promotion of corporate culture The important position in ideological work needs to be more clear, and the guiding role needs to be more prominent.

\section{ACKNOWLEDGMENT}

This project is supported by the State Grid Corporation of China Management Consulting Project "Research on Implementing the Company's Strategic Objectives and Strengthening the Construction of Corporate Culture" (SGZB0000ZGWT2100881).

\section{REFERENCES}

[1] Yang, J., Corporate Culture Construction, in: New Business Weekly., vol.11, Beijing, China, 2018, pp.146. DOI:10.3969/j.issn.2095-4395.2018.11.130.

[2] Li, J., On the Basic Principles of Corporate Culture Construction, in: Journal of Yunnan Nationalities University (Philosophy and Social Sciences Edition)., vol.11, Beijing, China, 2005, pp.22-25. DOI:10.3969/j.issn.1672-867X.2005.03. 005.

[3] Ma, J., Research on Innovation Countermeasures of Governmental Work in State-owned Enterprises Based on Corporate Culture, in: Market Observation., vol.8, Beijing, China, 2020, pp.58. DOI:10.3969/j.issn.1674-1315.2020.08.033.

[4] Zhang, L., Analysis of the Innovation Strategy of State-owned Enterprises' Political Work Based on Corporate Culture, in: Office Business., vol.1, Beijing, China, 2021, pp.34-35. DOI:10.3969/j.issn.1004-647X.2021.01.017. 